I N S T I T U T O

$\mathrm{DE}$

M E D I C I N A

T R O P I C A L

$\mathrm{DE}$

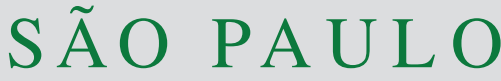

JOURNAL OF THE SÃO PAULO INSTITUTE OF TROPICAL MEDICINE

${ }^{1}$ China Academy of Traditional Chinese Medical Sciences, Guang'anmen Hospital, Department of Radiology, Xicheng District, Beijing, China

${ }^{2}$ Hubei University of Arts and Science, Xiangyang Central Hospital, Department of Radiology, Xiangyang City, Hubei, China

${ }^{3}$ Xiangyang Hospital of Integrated Traditional Chinese and Western Medicine, Department of Radiology, Xiangyang City, Hubei, China

"these authors contribute equally as first authors

Correspondence to: Yang Xuedong China Academy of Traditional Chinese Medical Sciences, Guang'anmen Hospital, Department of Radiology, Beixian'ge Road 5, Xicheng District, 100053, Beijing, China Tel: +86 13811059499

E-mail: yangxuedong1@163.com

Received: 13 April 2020

Accepted: 16 September 2020
http://doi.org/10.1590/S1678-9946202062076

\section{Spontaneous pneumomediastinum, pneumothorax and subcutaneous emphysema in COVID-19: case report and literature review}

\author{
Shi Shan ${ }^{\oplus 1 *}$, Li Guangming ${ }^{2 *}$, Lei Wei ${ }^{3}$, Yang Xuedong ${ }^{1}$
}

\section{ABSTRACT}

Coronavirus Disease 2019 (COVID-19) has rapidly spread worldwide. Numerous studies have shown its typical and atypical CT findings. We report one COVID-19 patient who presented with a transient pneumothorax, spontaneous pneumomediastinum (SP), as well as subcutaneous emphysema during hospitalization. Chest CT andclinical findings were discussed, and a literature review is presented. The probable cause of SP in COVID-19 was alveolar damage. Once pneumothorax and SP were present, the patient should be carefully monitored to prevent respiratory deterioration, especially when lung lesions are severe.

KEYWORDS: Spontaneous pneumomediastinum. Pneumothorax. Alveolar damage.

\section{INTRODUCTION}

Since the outbreak of Coronavirus Disease 2019 (COVID-19), it has quickly spread worldwide. Globally, people infected were more than 8.5 million and deaths are over 0.4 million on June $19^{\text {th }}$, according to the Johns Hopkins University's COVID-19 map.

The common CT manifestations of COVID-19 include pure ground-glass opacities (GGO), GGO with reticular opacities, GGO with consolidation, as well as consolidations. Bilateral lung involvement is frequent, especially in the posterior parts and peripheral areas. Pleural effusion, pericardial effusion and lymphadenopathy are rarely $\operatorname{seen}^{1-3}$. Spontaneous pneumomediastinum (SP) and pneumothorax are extremely rare in COVID-19, up to now a total of eight cases have been reported in the literature ${ }^{4-11}$. We have also found one COVID-19 patient who showed SP, pneumothorax, as well as subcutaneous emphysema during treatment.

\section{CASE REPORT}

A 67-year-old man who worked in Wuhan, Hubei Province, China, returned to Xiangyang city from Wuhan on January $19^{\text {th }}, 2020$. Fever occurred since that day, and the highest temperature was $38.5^{\circ} \mathrm{C}$. The patient showed occasional cough, shortness of breathe after activity, without expectoration, obvious dyspneaand diarrhea. $\mathrm{He}$ had a 5-year history of hypertension and no other underlying diseases. On February $7^{\text {th }} 2020$, a real-time reverse transcription-polymerase chain reaction (RT-PCR) for the COVID-19 was positive. Laboratory tests carried out on February $7^{\text {th }}$ showed that $\mathrm{SpO}$, blood oxygen saturation, lymphocyte ratio and lymphocyte count were decreased; on the contrary, C-reactive protein, Erythrocyte sedimentation rate, 
neutrophil count, neutrophil ratio and LDH were elevated; the liver test was also abnormal, and the tests results are shown in Table 1.

Chest CT was performed on January $28^{\text {th }} 2020$ (Figure 1), on February $5^{\text {th }}$ (Figure 2), on February $11^{\text {th }}$
(Figure 3) and on March $3^{\text {rd }}$ (Figure 4), respectively. Typical CT manifestations were found in the initial images, which included bilateral GGO with reticular opacities predominantly located in the periphery on January $28^{\text {th }}$; bilateral lung lesions progressed on February

Table 1 - Laboratory test results on February $7^{\text {th }}$ and $14^{\text {th }} 2020$.

\begin{tabular}{lcc}
\hline Test & Value (local reference range) February $7^{\text {th }}$ & Value on February $14^{\text {th }}$ \\
\hline SpO2 & $93 \%(95-99 \%)$ & $96 \%$ \\
blood oxygen saturation & $88 \%(98 \%)$ & - \\
lymphocyte ratio & $7.1 \%(20-40 \%)$ & $8.9 \%$ \\
lymphocyte count & $0.58 \times 10^{\wedge} 9 / \mathrm{L}\left(1.1-3.2 \times 10^{\wedge} 9\right)$ & $1.10 \times 10^{\wedge} 9 / \mathrm{L}$ \\
neutrophil ratio & $89.5 \%(40-75 \%)$ & $86.1 \%$ \\
neutrophil count & $7.30 \times 10^{\wedge} / \mathrm{L}\left(1.8-6.3 \times 10^{\wedge} 9 / \mathrm{L}\right)$ & $10.69 \times 10^{\wedge 9} / \mathrm{L}$ \\
C-reactive protein & $110.00 \mathrm{mg} / \mathrm{L}(0.8-8 \mathrm{mg} / \mathrm{L})$ & - \\
Erythrocyte sedimentation rate & $40 \mathrm{~mm} / \mathrm{h}(0-15 \mathrm{~mm} / \mathrm{h})$ & - \\
LDH & $384 \mathrm{U} / \mathrm{L}(110-240 \mathrm{U} / \mathrm{L})$ & $257 \mathrm{U} / \mathrm{L}$ \\
ALT & $106 \mathrm{U} / \mathrm{L}(30 \mathrm{U} / \mathrm{L})$ & $26 \mathrm{U} / \mathrm{L}$ \\
AST & $28 \mathrm{U} / \mathrm{L}(29-35 \mathrm{U} / \mathrm{L})$ & $25 \mathrm{U} / \mathrm{L}$ \\
\hline
\end{tabular}

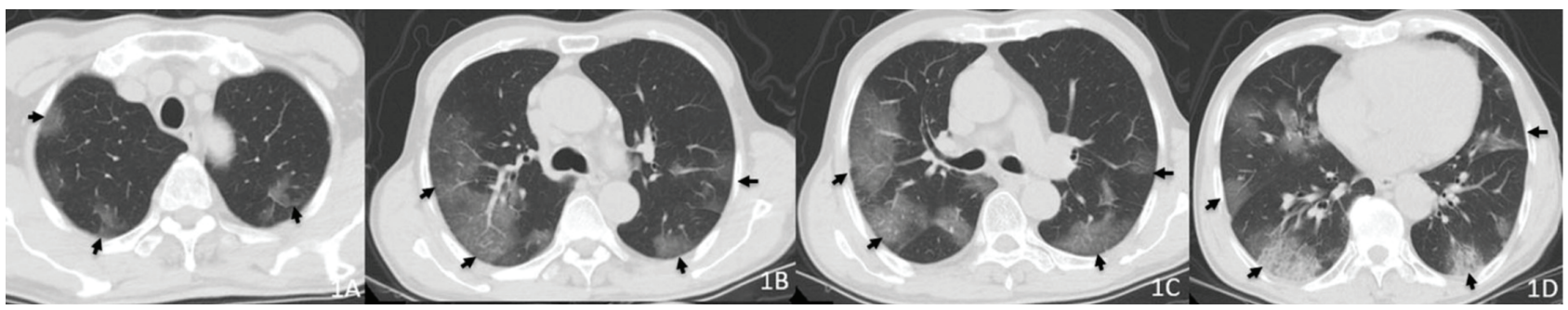

Figure 1 - Chest CT (performed with a Philips Ingenuity 128 CT Scanner, $5 \mathrm{~mm}$ slice thickness reconstruction) showing multiple GGO (short arrow) mainly on the periphery of both lungs, some lesions with reticular opacities.

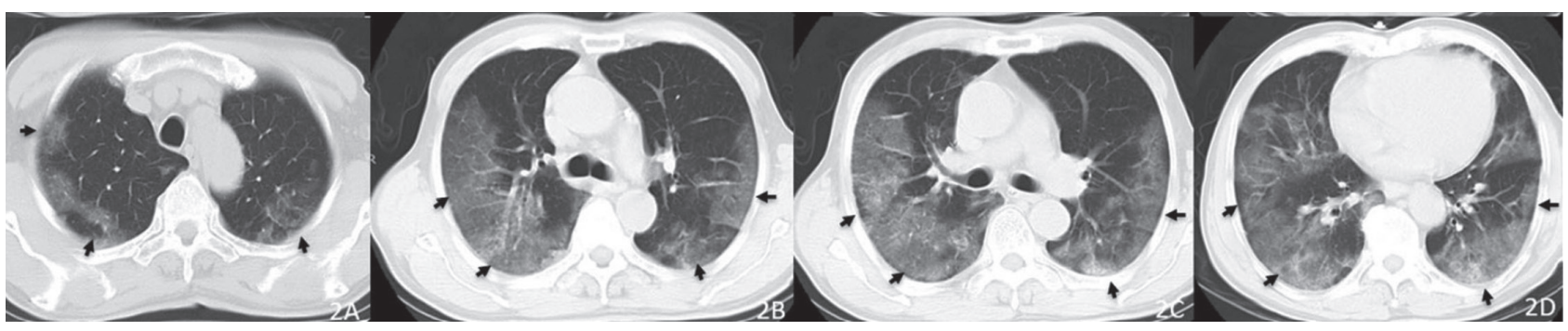

Figure 2 - GGO (short arrow) range was larger than before, with diffuse distribution in both lungs, some lesions with reticular opacities.

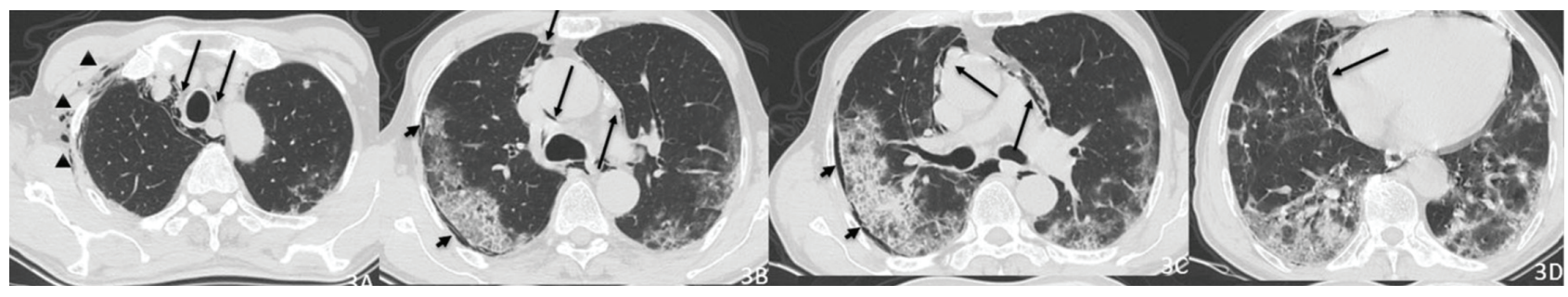

Figure 3 - CT demonstrated GGO with consolidation in both lungs, some lesions with reticular opacities, the range slightly smaller than before. Distortion of lung structures was noted. Subcutaneous emphysema within the right upper chest wall (black triangle) and neck (not shown), SP (long arrow), as well as a small pneumothorax in the right chest (short arrow) appeared. 


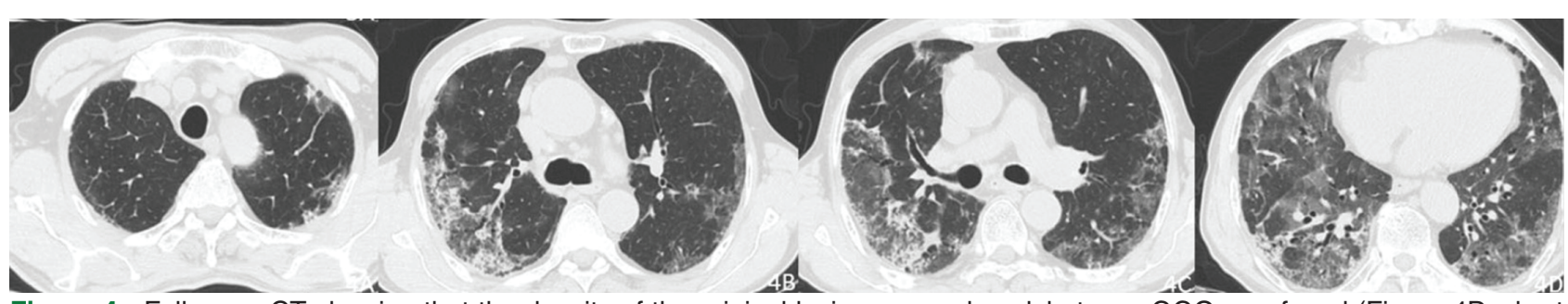

Figure 4 - Follow-up CT showing that the density of the original lesion was reduced; but new GGO was found (Figure 4D, short arrow). Subcutaneous emphysema, SP and pneumothorax had been completely absorbed.

$5^{\text {th }}$; subcutaneous emphysema in the upper right part of the chest and neck, SP, and pneumothorax in the right chest occurred on February $11^{\text {th }}$ (the last laboratory examination since the occurrence of mediastinal emphysema was on February $14^{\text {th }}$ and the laboratory test results are shown in Table 1). The pulmonary lesions were treated conservatively and by March $3^{\text {rd }}$ the CT images had totally regressed.

Clinical treatment mainly included an antibiotic (Ceftazidime), an anti-viral (Arbidol), low-dose methylprednisolone intravenous drip therapy $(1 \mathrm{mg} / \mathrm{kg})$, and symptomatic supportive therapy adjusted according to the clinical conditions. Low-flow nasal catheter at $3 \mathrm{~L} / \mathrm{min}$ of oxygen was used. No invasive ventilation was performed during the period of hospitalization. The patient was tested by RT-PCR for COVID-19 on March $4^{\text {th }}$ and March $5^{\text {th }}$ 2020 and both tests were negative. Informed consent was obtained from the patient.

\section{DISCUSSION}

SP refers to a pneumomediastinum occurring in circumstances other than traumatic or of iatrogenic origin ${ }^{12}$. This patient did not undergo any invasive ventilation or surgical procedures during hospitalization, so that the pneumomediastinum was spontaneous.

In a previous study, SP developed in $11.6 \%$ of SARS patients and appeared 19.6 \pm 4.6 days after the onset of symptoms $^{13}$. The SP in the COVID-19 patient reported here was diagnosed 23 days after the onset of symptoms, which was similar to those in SARS patients. The pulmonary pathology of COVID-19 greatly resembles the one seen in SARS, showing diffuse alveolar damage, cellular fibromyositis exudates, evident desquamation of pneumocytes and hyaline membrane formation ${ }^{14}$. We believe that the possible causes of SP in COVID-19 were similar to those in SARS. The alveolar rupture as a consequence of severe diffuse alveolar damage ${ }^{13}$ and episodes of coughing or Valsalva maneuver that increase the pressure in the chest as inducing factors, then causing interstitial emphysema, and air dissection along the bronchovascular sheaths into the mediastinum
$(\mathrm{SP})^{15}$. This can also help to explain why pneumothorax and subcutaneous emphysema occur simultaneously. In this case, pneumothorax and SP occurred after the progression of lung lesions (February $5^{\text {th }}$ ), suggesting that the occurrence of emphysema may be related to alveolar damage.

SP is generally a benign disease that may not need specific treatment and can be absorbed spontaneously. In the case reported here the SP was self-limited. SP, pneumothorax and subcutaneous emphysema were completely absorbed 21 days later. In SARS, high LDH level was associated with SP, and the development of SP was also associated with poor prognosis ${ }^{13}$. In this case, the maximum LDH was $384 \mathrm{U} / \mathrm{L}$, considerably lower than the LDH levels in SP of SARS (LDH of $863 \mathrm{U} / \mathrm{L})^{13}$. In the reported case, SP completely absorbed, and the patient's conditions improved and stabilized. Therefore, the relationship between SP and LDH elevation, and also with prognosis has yet to be further studied.

Recent literature has reported eight cases of SP and pneumothorax in COVID-19, M: $\mathrm{F}=5: 3$, the average age was $44.0 \pm 19.7$ years, one of the patients eventually died and the other seven patients finally recovered after conservative treatment, needle decompression or catheter chest drainage. The patient who died had extremely severe lung lesions that progressed rapidly ${ }^{8}$ (Table 2). Therefore, the prognosis of SP and pneumothorax may be related to the severity of pulmonary lesions, but there is no clear correlation with the magnitude of pneumothorax and SP. As pneumothorax and SP are found, the patient should be carefully monitored to prevent respiratory deterioration, especially when the lung lesions are severe.

\section{CONCLUSIONS}

SP, pneumothorax and subcutaneous emphysema are extremely rare in COVID-19. The probable cause of SP in COVID-19 in the reported case was alveolar damage. SP and pneumothorax may be related to death when SP and pneumothorax are found, and the patient should be carefully monitored to prevent respiratory deterioration. 
Table 2 - Detailed description of patients with spontaneous pneumomediastinum and/or pneumothorax in COVID-19 in recent reports.

\begin{tabular}{|c|c|c|c|c|c|}
\hline Authors & Age/Sex & Image alterations & Lung lesion & Respiratory support & Clinical outcome \\
\hline Kolani et al. ${ }^{4}$ & $23 / F$ & $\begin{array}{l}\text { Small amount } \\
\text { of spontaneous } \\
\text { pneumomediastinum, } \\
\text { no emphysema or } \\
\text { pneumothorax }\end{array}$ & $\begin{array}{l}\text { Inconspicuous } \\
\text { ground glass opacity } \\
\text { in the lower left } \\
\text { inferior lobe }\end{array}$ & No & Recovered \\
\hline Zhou et al. ${ }^{5}$ & $38 / \mathrm{M}$ & $\begin{array}{c}\text { Spontaneous } \\
\text { pneumomediastinum } \\
\text { and subcutaneous } \\
\text { emphysema }\end{array}$ & $\begin{array}{l}\text { Multiple ground- } \\
\text { glass opacities with } \\
\text { bilateral parenchymal } \\
\text { consolidation and } \\
\text { interlobular septal } \\
\text { thickening }\end{array}$ & $\begin{array}{l}\text { Supplemental } \\
\text { oxygen }\end{array}$ & Recovered \\
\hline Wang et al. ${ }^{6}$ & $62 / \mathrm{M}$ & $\begin{array}{c}\text { Spontaneous } \\
\text { pneumothorax, } \\
\text { pneumomediastinum } \\
\text { and subcutaneous } \\
\text { emphysema }\end{array}$ & $\begin{array}{c}\text { Multiple ground- } \\
\text { glass opacities } \\
\text { with parenchymal } \\
\text { consolidation, } \\
\text { pneumothorax on the } \\
\text { right }\end{array}$ & $\begin{array}{l}\text { High-flow nasal } \\
\text { cannula }\end{array}$ & Recovered \\
\hline Mohan and Tauseen ${ }^{7}$ & $49 / \mathrm{M}$ & $\begin{array}{c}\text { Severe } \\
\text { pneumomediastinum } \\
\text { with extensive } \\
\text { subcutaneous } \\
\text { emphysema mainly } \\
\text { extending superiorly in } \\
\text { the thorax and to the } \\
\text { neck without evidence of } \\
\text { pneumothorax }\end{array}$ & $\begin{array}{l}\text { Bilateral patchy } \\
\text { infiltrates mainly } \\
\text { distributed in the } \\
\text { middle and lower } \\
\text { lung lobes. }\end{array}$ & $\begin{array}{c}\text { Non-invasive } \\
\text { supplemental oxygen }\end{array}$ & Recovered \\
\hline Wang et al. ${ }^{8}$ & $36 / F$ & $\begin{array}{c}\text { Spontaneous } \\
\text { pneumomediastinum }\end{array}$ & $\begin{array}{l}\text { Multiple diffuse } \\
\text { patchy consolidation } \\
\text { areas and ground- } \\
\text { glass opacities in } \\
\text { both lungs the total } \\
\text { lung severity score } \\
\text { of the patient was } 19 \\
\text { out of } 20\end{array}$ & $\begin{array}{l}\text { Noninvasive } \\
\text { ventilation }\end{array}$ & Died \\
\hline Ucpinar et al. ${ }^{9}$ & $82 / F$ & $\begin{array}{l}\text { Spontaneous } \\
\text { pneumomediastinum, } \\
\text { left sided massive } \\
\text { pneumothorax, } \\
\text { subcutaneous } \\
\text { emphysema in the neck } \\
\text { posterior thoracic wall }\end{array}$ & $\begin{array}{l}\text { Widespread bilateral } \\
\text { GGO, predominantly } \\
\text { in lower lobes }\end{array}$ & No & Recovered \\
\hline Flower et al. ${ }^{10}$ & $36 / \mathrm{M}$ & $\begin{array}{l}\text { Left- sided tension } \\
\text { pneumothorax }\end{array}$ & $\begin{array}{l}\text { Widespread areas of } \\
\text { patchy consolidation }\end{array}$ & No & Recovered \\
\hline Rohailla et al. ${ }^{11}$ & $26 / M$ & $\begin{array}{l}\text { Large right } \\
\text { pneumothorax with } \\
\text { complete collapse of the } \\
\text { right lung }\end{array}$ & $\begin{array}{l}\text { No defined } \\
\text { intrapulmonary } \\
\text { inflammation was } \\
\text { found on chest } \\
\text { radiograph }\end{array}$ & No & Recovered \\
\hline
\end{tabular}

\section{REFERENCES}

1. Zu ZY, Jiang MD, Xu PP, Chen W, Ni QQ, Lu GM, et al. Coronavirus disease 2019 (COVID-19): a perspective from China. Radiology. 2020;296:E15-25.

2. Chung M, Bernheim A, Mei X, Zhang N, Huang M, Zeng X, et al. CT Imaging features of 2019 novel Coronavirus (2019-nCoV).
Radiology. 2020;295:202-7.

3. Song F, Shi N, Shan F, Zhang Z, Shen J, Lu H, et al. Emerging 2019 novel Coronavirus (2019-nCoV) pneumonia. Radiology. 2020;295:210-17.

4. Kolani S, Houari N, Haloua M, Lamrani YA, Boubbou M, Serraj $\mathrm{M}$, et al. Spontaneous pneumomediastinum occurring in the SARS-COV-2 infection. IDCases. 2020;21:e00806. 
5. Zhou C, Gao C, Xie Y, Xu M. COVID-19 with spontaneous pneumomediastinum. Lancet Infect Dis. 2020;20:510.

6. Wang W, Gao R, Zheng Y, Jiang L. COVID-19 with spontaneous pneumothorax, pneumomediastinum and subcutaneous emphysema. J Travel Med. 2020;27:taaa062.

7. Mohan V, Tauseen RA. Spontaneous pneumomediastinum in COVID-19. BMJ Case Rep. 2020;13:e236519.

8. Wang J, Su X, Zhang T, Zheng C. Spontaneous pneumomediastinum: a probable unusual complication of Coronavirus disease 2019 (COVID-19) pneumonia. Korean J Radiol. 2020;21:627-8.

9. Ucpinar BA, Sahin C, Yanc U. Spontaneous pneumothorax and subcutaneous emphysema in COVID-19 patient: case report. J Infect Public Health. 2020;13:887-9.

10. Flower L, Carter JL, Rosales Lopez J, Henry AM. Tension pneumothorax in a patient with COVID-19. BMJ Case Rep. 2020;13:e235861.
11. Rohailla S, Ahmed N, Gough K. SARS-CoV-2 infection associated with spontaneous pneumothorax. CMAJ. 2020;192:E510.

12. Sahni S, Verma S, Grullon J, Esquire A, Patel P, Talwar A. Spontaneous pneumomediastinum: time for consensus. N Am J Med Sci. 2013;5:460-4.

13. Chu CM, Leung YY, Hui JY, Hung IF, Chan VL, Leung WS, et al. Spontaneous pneumomediastinum in patients with severe acute respiratory syndrome. Eur Respir J. 2004;23:802-4.

14. Xu Z, Shi L, Wang Y, Zhang J, Huang L, Zhang C, et al. Pathological findings of COVID-19 associated with acute respiratory distress syndrome. Lancet Respir Med. 2020;8:420-2.

15. Wintermark M, Schnyder P. The Macklin effect: a frequent etiology for pneumomediastinum in severe blunt chest trauma. Chest. 2001;120:543-7. 